\title{
Selected Lipid Profile in the Serum \& Tissues of Weaned Male Albino Rats Fed on Processed Atlantic Horse Mackerel (Trachurus trachurus)
}

\author{
Olaoluwa T. Adeyemi1 ${ }^{*}$, Odutola Osilesi', Olugbenga O. Adebawo1, Funmilayo D. Onajobi, \\ Sunday 0. Oyedemi² \\ ${ }^{1}$ Department of Biochemistry, Bencarson School of Medicine, Babcock University, Ilishan Remo, Nigeria \\ ${ }^{2}$ Botany Department, University of Fort Hare, Alice, South Africa \\ Email: olaoluwatemi@yahoo.com, odutola.osilesi@gmail.com, ooadebawo@yahoo.co.uk, \\ fonajobi@yahoo.com, silvanusdemi@yahoo.com
}

Received 19 March 2015; accepted 15 April 2015; published 20 April 2015

Copyright (C) 2015 by authors and Scientific Research Publishing Inc.

This work is licensed under the Creative Commons Attribution International License (CC BY).

http://creativecommons.org/licenses/by/4.0/

(c) (i) Open Access

\begin{abstract}
Trachurus trachurus (locally called kote) is a low cost table fish in south-west Nigeria. Study was conducted to determine the effect of processed kote on total triglycerides (TG) \& cholesterol (Chol) in the serum as well as lactate dehydrogenase (LDH), creatinine (CRT), Chol and glucose (Gluc) in selected tissues of weaned male albino rats using standard methods. Chemical analyses were carried out on processed fillet; skin, head \& bone (SHB) diets under standard conditions. 40 male rats were fed with processed fillet or SHB diets for 14 days to assay TG \& Chol in serum as well as the activities of LDH \& CRT in the heart, kidney, brain, spleen and small intestine; in addition to Chol and Gluc levels in the brain and liver. All data were subjected to analysis of variance by Duncan's multiple range test. Results indicated that levels of serum triglycerides and total cholesterol, as well as LDH and Gluc in the liver, heart, kidney and brain were reduced $(p<0.05)$ in rats fed on test diets compared to the controls, but within accepted limit. Levels of LDH and CRT in the kidney, stomach and small intestine were elevated $(p<0.05)$ compared to the controls, but within the accepted limit. Overall the coal smoked SHB was the best diet in terms of reduced levels of Chol \& TG as well as healthy growth of the rats, followed by wood smoked diets. Thus, processed kote SHB could be a useful source of valuable nutrients in animal feed.
\end{abstract}

\section{Keywords}

Processed Kote, Triglycerides, Total Cholesterol, Lactate Dehydrogenase, Creatinine and Glucose

\footnotetext{
${ }^{*}$ Corresponding author.
}

How to cite this paper: Adeyemi, O.T., Osilesi, O., Adebawo, O.O., Onajobi, F.D. and Oyedemi, S.O. (2015) Selected Lipid Profile in the Serum \& Tissues of Weaned Male Albino Rats Fed on Processed Atlantic Horse Mackerel (Trachurus trachurus). Advances in Bioscience and Biotechnology, 6, 286-301. http://dx.doi.org/10.4236/abb.2015.64028 


\section{Introduction}

Trachurus trachurus, one of the most important sources of animal protein available in the tropics, in recent times has been widely accepted as a good source of protein and other vital nutrients [1]. The healthiest fatty acids are found in fish oil, while their tissues are the main source of long chain polyunsaturated fatty acids. These polyunsaturated fatty acids (PUFA) (omega-6 or linoleic and especially omega-3 or linolenic acids) are recognized as essential biochemical components of human diet. Humans obtain these essential components from marine or freshwater products [2]. Fish is not usually eaten raw and so it must be processed, different processing mehods like smoking, poaching, canning, salting etc. are often used to increase the shelf life, digestibility and the palatability of fish products [3].

Cardiovascular disease is one of the major health problems in the world. It is dramatically increasing in the last 10 years [4]. Blood lipid profile determines the risk of cardiac disease. Lipid profile includes total cholesterol (TC), high density lipoprotein cholesterol (HDL-C) often called good cholesterol, low density lipoprotein cholesterol (LDL-C) often called bad cholesterol and triglycerides (TG). An extended profile may also include very low density lipoprotein cholesterol (VLDL-C) and Non-HDL-C.

Cardiac complication is a lifestyle disease. The major cause of this disease is due to high intake of cholesterol containing foods. Dietary saturated fatty acid increase blood cholesterol level, while polyunsaturated fatty acids (PUFAs) reduce blood cholesterol. Previous studies have shown that fish and vegetable oils contain polyunsaturated fatty acids (PUFAs), which reduce blood lipid profile. Fish oil contains $\omega$-3 PUFAs and is more effective than vegetable oil which contains the $\omega$-6-PUFAs [5]. Epidemiological studies show that eating fish increases HDL and decreases blood cholesterol and LDL levels; thus reducing the risk of coronary death [6] Rahman, 2014). It is also shown that high concentrations of HDL (over $60 \mathrm{mg} / \mathrm{dl}$ ) have protective effect against cardiovascular diseases such as ischemic stroke and myocardial infarction but higher LDL promotes cardiovascular disease. Very low LDL increases the risk of cardiovascular disease, if their HDL level is not high [7].

T. trachurus is often harvested in the Tropical countries, East Atlantic and Mediterranean seas. It ingests mainly on crustaceans, zooplankton, gadoids and herring which are rich in saturated fatty acids (SFA) and polyunsaturated fatty acids (PUFA) [8]. High levels of $\omega$-3 is of great importance in our diets because, levels of $\omega-3 / \omega-6$ ratio have been suggested to be a better index for comparing the relative nutritional value of different species [9]. Sargent [10] indicated that the acceptable optimum dietary ratio for $\omega-3 / \omega-6$ PUFA is $1: 5(0.2)$. The higher the $\omega-3 / \omega-6$ ratios, the better the body is able to use the $\omega-3$ fatty acids in decreasing the production of cytokines [11]. Omega-3 fatty, Eicosapentaenoic acid (EPA) also helps to temper inflammatory responses by decreasing production of pro-inflammatory compounds such as cytokines [12]. While the omega-6 fatty acids e.g. Arachidonic acids are pro-inflammatory, therefore the ratio of $\omega-3 / \omega$-6 PUFA higher than 1:5 (0.2) are potentially dangerous food for people with heart diseases, asthma, arthritis, allergic and auto immune diseases [13].

In addition, Toppe et al., [14], suggested that bones from whole fish and cut offs from both the raw and processed fish could be used as raw material for health products, human nutrition and animal feed industry. Thus the skin, head and bone of these fish (T. trachurus) may contain some vital nutritive values that are considered insignificant by majority of the people. The present study was therefore conducted to provide scientific data on the effect of processed Trachurus trachurus fillet; skin, head and bones (SHB) on the total cholesterol \& triglycerides as well as activities of lactate dehydrogenase (LDH), creatinine (CRT), cholesterol and glucose levels in the brain, liver, kidney, heart, stomach, small intestine and spleen of weaned male wistar rats.

\section{Materials and Methods}

\subsection{Sample Processing}

The mean length and weight of Trachurus trachurus were: $30.52 \pm 0.22 \mathrm{~cm}$ and $197.66 \pm 3.67 \mathrm{~g}$ respectively. Freshly purchased fish, packed in ice polystyrene boxes were transported to the laboratory within $30 \mathrm{~min}$. The fish was thoroughly washed and drained, placed on wire gauze and cooked by poaching or smoking (firewood or charcoal). Poaching of the fish was done according to the method described by USDA [15], modified by Larsen [16]. The procedure was followed without addition of any ingredient. T. trachurus weighing $7 \mathrm{~kg}$ was hot smoked using either firewood or charcoal in Altona smoke kiln as described by FAO/UN [17]. The smoking time, temperature and ambient conditions were monitored during the smoking operation. Smoking was termi- 
nated when fish was properly dried to an average moisture content of $10.41 \% \pm 0.02 \%$, after 8 hours. The fish was turned at intervals and the smoked or poached fish samples kept in cane woven baskets, under laboratory conditions with no preservative, left to cool and subsequently packaged in low density and high-density polyethylene bag, sealed then stored at $8^{\circ} \mathrm{C}$ until required for further use.

\subsection{Rat Diets Formulation}

Yellow maize (Zea mays) was purchased from Alice market, South Africa. The maize was soaked in warm water and changed daily for four days to soften the outer coat in preparation for milling. The corn was dried at $40^{\circ} \mathrm{C}$ to constant weight using the Prolab Electrical Oven and milled to smooth powder using Polymix dispersion and mixing Technology Kinemation Switzerland Blender. The animal diets were formulated following the protocol of Food and Agricultural Organization [18]. The gross and chemical compositions of control and test diets formulated are shown in Table 1. A protein-free diet served as a negative control whereas the processed fish varieties (fillet and SHB) served as protein source in the experimental diets. All the diets for the experiment provided a minimum of $10 \%$ protein. Soy bean meal and groundnut cake were used as the protein source in the positive control. Both diets contained equal amounts of DL-methionine, sucrose, wheat meal, vitamin mix and mineral mix.

\subsection{Proximate Analysis of Formulated Diets}

Raw and processed fish samples were oven dried to constant weight at $60^{\circ} \mathrm{C}$, fish fillet was separated from its skin, head and bones (SHB). Fish fillet or SHB was grounded to powder using a monillex kitchen blender for protein concentrate. The feed samples were analyzed for moisture and ash content [19]. Total crude fat was determined using the Soxhlet extraction method according to [19] and Reinik et al. [20]. The crude fiber content was estimated by acid-base digestion method [19]. Crude protein content was determined by the Kjeldahl method described by [21]. Percentage nitrogen was calculated using the equation $\mathrm{Y}=0.026 \mathrm{x}-0.003$ and $\mathrm{R}^{2}=$ 0.974 obtained from the calibration curve after nitrogen content determination [22]. Crude protein was estimated by multiplying the nitrogen value by the converting factor of 6.25 .

\subsection{Experimental Animals}

A total of 40 weaned male wister rats weighing between 30 and $40 \mathrm{~g}$ were obtained from the animal house of Central Analytical Laboratory, University of Fort Hare. The animals were kept in clean Plexiglas cages and

Table 1. Gross and proximate composition (\%) of experimental (fillet and SHB) based diets.

\begin{tabular}{ccccccc}
\hline Parameters & Protein & Fat & Ash & Crude fibre & Moisture & CHO \\
\hline${ }^{\gamma}$ S-GBD & $13.76 \pm 4.91^{\mathrm{b}}$ & $2.15 \pm 0.01^{\mathrm{b}}$ & $3.17 \pm 0.17^{\mathrm{c}}$ & $8.43 \pm 0.01^{\mathrm{b}}$ & $46.67 \pm 0.17^{\mathrm{a}}$ & $28.19 \pm 0.96^{\mathrm{b}}$ \\
${ }^{\dagger}$ S-GBD & $13.76 \pm 4.91^{\mathrm{a}}$ & $2.15 \pm 0.01^{\mathrm{c}}$ & $3.17 \pm 0.17^{\mathrm{c}}$ & $8.43 \pm 0.01^{\mathrm{c}}$ & $46.67 \pm 0.17^{\mathrm{a}}$ & $28.19 \pm 0.96^{\mathrm{a}}$ \\
${ }^{\gamma}$ ZPD & $11.52 \pm 4.35^{\mathrm{d}}$ & $2.86 \pm 0.03^{\mathrm{b}}$ & $3.17 \pm 0.17^{\mathrm{c}}$ & $8.30 \pm 0.10^{\mathrm{b}}$ & $47.50 \pm 0.50^{\mathrm{a}}$ & $24.28 \pm 1.12^{\mathrm{c}}$ \\
${ }^{\dagger}$ ZPD & $11.52 \pm 4.35^{\mathrm{b}}$ & $2.86 \pm 0.03^{\mathrm{c}}$ & $3.17 \pm 0.17^{\mathrm{c}}$ & $8.30 \pm 0.10^{\mathrm{c}}$ & $47.50 \pm 0.50^{\mathrm{a}}$ & $24.28 \pm 1.12^{\mathrm{b}}$ \\
CSKFBD & $14.62 \pm 2.23^{\mathrm{a}}$ & $3.24 \pm 0.08^{\mathrm{a}}$ & $5.5 \pm 0.29^{\mathrm{a}}$ & $6.36 \pm 0.01^{\mathrm{d}}$ & $38.17 \pm 1.42^{\mathrm{b}}$ & $32.11 \pm 0.81^{\mathrm{a}}$ \\
CSHBBD & $10.44 \pm 3.32^{\mathrm{c}}$ & $5.03 \pm 0.08^{\mathrm{a}}$ & $7.67 \pm 0.44^{\mathrm{a}}$ & $19.06 \pm 0.03^{\mathrm{b}}$ & $40.17 \pm 1.09^{\mathrm{b}}$ & $17.63 \pm 1.92^{\mathrm{d}}$ \\
WSKFBD & $12.43 \pm 3.24^{\mathrm{c}}$ & $3.45 \pm 0.09^{\mathrm{a}}$ & $6.17 \pm 0.17^{\mathrm{a}}$ & $13.18 \pm 0.02^{\mathrm{a}}$ & $47.00 \pm 1.00^{\mathrm{a}}$ & $17.77 \pm 0.97^{\mathrm{d}}$ \\
WSHBBD & $12.68 \pm 3.28^{\mathrm{b}}$ & $5.62 \pm 0.26^{\mathrm{a}}$ & $4.5 \pm 0.00^{\mathrm{b}}$ & $18.90 \pm 0.03^{\mathrm{b}}$ & $46.17 \pm 0.33^{\mathrm{a}}$ & $12.13 \pm 0.78^{\mathrm{e}}$ \\
PKFBD & $14.66 \pm 1.01^{\mathrm{a}}$ & $3.05 \pm 0.01^{\mathrm{a}}$ & $3.5 \pm 0.00^{\mathrm{b}}$ & $7.85 \pm 0.09^{\mathrm{c}}$ & $46.50 \pm 0.00^{\mathrm{a}}$ & $24.44 \pm 0.21^{\mathrm{c}}$ \\
PSHBBD & $14.25 \pm 2.45^{\mathrm{a}}$ & $3.69 \pm 0.02^{\mathrm{b}}$ & $8.17 \pm 0.33^{\mathrm{a}}$ & $24.82 \pm 0.01^{\mathrm{a}}$ & $29.00 \pm 3.00^{\mathrm{c}}$ & $20.07 \pm 0.82^{\mathrm{c}}$ \\
\hline
\end{tabular}

${ }^{*}$ Data $=$ Mean \pm SEM, $\mathrm{n}=3$. Values with different superscripts along a row are significantly different (p < 0.05). CSKFBD: charcoal smoked kote fillet meal based diet; WSKFBD: wood smoked kote fillet meal based diet; PKFBD: poached kote fillet meal based diet; CSHBBD: charcoal smoked kote SHB meal based diet; WSHBBD: wood smoked kote SHB meal based diet; PSHBBD: poached kote SHB meal based diet S-GBD: Soy bean \& Groundnut cake meal based diet (Positive control); ZPD: Zero protein diet (Negative control). ${ }^{\dagger}$ stands for SHB group and ’stands for fillet fed group; CHO stands for carbohydrate. 
maintained at a controlled temperature $24^{\circ} \mathrm{C}$ with a 12 hour light-dark cycle and relative humidity of $45 \%$ - 50\%. They were fed with formulated diets or standard rat feed with water ad-libitum for 12 days. All animal experiments were conducted under NIH guidelines for care and use of laboratory animals after approval of animal ethics committee of the University of Fort Hare, South Africa.

\subsection{Animal Experimental Design}

Animals were randomly distributed into eight treatment groups with mean weight differing within \pm 2.00 g: Group I: animal administered soya bean-groundnut cake meal (positive control). Group II: animals received basal diet (zero protein or negative control). Group III: animals received poached fillet diet. Group IV: animals treated with coal smoked fillet diet. Group V: animals fed with wood smoked fillet diet. Group VI: animals fed with poached SHB diet. Group VII: animals received coal smoked SHB diet. Group VIII: animals administered with wood smoked SHB diet for 12 days. Individual weights of the rats were taken prior to commencement of the experiment and afterwards on 4 day interval. Feed and water intake of rats were measured on a daily basis, while the cages were cleaned on 4th day, by which time the rat faces were collected. At the end of experiment the rats were sacrificed. Individual blood samples were analyzed for triglycerides \& total cholesterol as well as activities of lactate dehydrogenase (LDH) and creatinine (CRT) in the heart \& kidney in addition to cholesterol and glucose levels of the brain liver, kidney, heart, stomach, small intestine and spleen.

\subsection{Proximate Analysis of Formulated Diets}

Raw and processed fish samples were oven dried to constant weight at $60^{\circ} \mathrm{C}$, and then fish fillet was separated from its skin, head and bones (SHB). Both fillet and SHB were grounded separately using a monillex kitchen blender, to produce protein concentrates. The feed samples were analyzed for moisture, protein, fat, ash, fiber and nitrogen free extract according to the methods of AOAC [19].

\subsubsection{Determination of Moisture Content}

Moisture content was determined by oven drying method. A dry crucible was weighed $\left(W_{1}\right)$ and $2.0 \mathrm{~g}$ of the well-mixed sample was accurately weighed into the crucible and weighed $\left(W_{2}\right)$. The crucible and the content were dried in an oven at $100^{\circ} \mathrm{C}-105^{\circ} \mathrm{C}$ for $12 \mathrm{~h}$. Length of oven-drying time was based on bringing the samples to a constant weight. Then the crucible plus the dried content was placed in a desiccator for 30 min to cool. After cooling samples were weighed again $\left(W_{3}\right)$; the percent moisture was calculated using the formula below:

$$
\text { \%Moisture }=\frac{W_{2}-W_{3}}{W_{2}-W_{1}} \times 100
$$

where $W_{1}=$ weight of crucible; $W_{2}=$ weight of crucible and sample; $W_{3}=$ weight of crucible and sample after drying.

\subsubsection{Determination of Crude Fat Content}

Crude fat was determined using the Soxhlet extraction method described by the [19]. $2.0 \mathrm{~g}$ of moisture free sample was weighed into a fat free thimble, plugged with cotton wool and then introduced into the extraction tube. A clean dry boiling flask was weighed $\left(W_{1}\right)$ and $250 \mathrm{ml}$ of petroleum ether was introduced into the flask and sample was extracted for 6 h continuously as described by Reinik et al. [20]. The extract was concentrated in a rotary evaporator (RE-100, Stone Staffordshire, and England) at $60^{\circ} \mathrm{C}$ to $2 \mathrm{ml}$. This was repeated for other samples. Then the remaining solvent removed from the extracted oil by placing the flask in the fume hood at $25^{\circ} \mathrm{C}$ for $45 \mathrm{~min}$ and weighed $\left(W_{2}\right)$. The percent crude fat was calculated by the following formula:

$$
\% \text { Fat }=\frac{W_{2}-W_{1}}{\text { Wt of sample }}
$$

where $W_{1}=$ weight of empty flask; $W_{2}=$ weight of flask and fat deposit.

\subsubsection{Determination of Crude Fiber Content}

Crude fiber was estimated by acid-base digestion following the method described by [19]. The residue obtained after lipid-extraction of $2 \mathrm{~g}$ from the sample was put in a $1 \mathrm{~L}$ beaker and $200 \mathrm{~mL}$ of boiling $2.5 \mathrm{M} \mathrm{H}_{2} \mathrm{SO}_{4}$ was 
added. The content was boiled for 30 min, cooled and filtered using a Buchner funnel followed by washing the residue three times with $50 \mathrm{~mL}$ boiling water. The washed residue was returned to the beaker for further digestion with $200 \mathrm{~mL}$ of $2.5 \mathrm{M} \mathrm{NaOH}$ for $30 \mathrm{~min}$. The resulting solution was filtered, washed three times with 50 $\mathrm{mL}$ boiling water and then $25 \mathrm{~mL}$ ethanol. The washed residue was dried in an oven at $130^{\circ} \mathrm{C}$ to constant weight and cooled in a desiccator. The residue was carefully scraped into pre-weighed porcelain crucible, weighed $\left(W_{1}\right)$ and ash at $550^{\circ} \mathrm{C}$ for $2 \mathrm{~h}$. It was cooled in a desiccator and re-weighed $\left(W_{2}\right)$. Crude fiber was expressed as percentage loss in weight after ignition.

$$
\text { Crude Fiber }(\%)=100-\frac{\left[W_{1}-W_{2}\right]}{W}
$$

where $W_{1}=$ weight (g) of crucible and content before ashing $W_{2}=$ weight (g) of crucible containing ash; $W=$ weight (g) of sample

\subsubsection{Determination of Crude Protein Content}

Total nitrogen (crude protein) was determined by the method of micro-Kjeldahl [21]. A known weight ( $0.5 \mathrm{~g})$ of dry and ground fish sample was weighed into a digestion tube. A volume of $12 \mathrm{~mL}(9 \mathrm{~mL}$ Nitric acid $+3 \mathrm{~mL}$ HCL) digestion mixture was added to the tubes. The mixture was then digested using the Buchi 425 digester from Switzerland at number 4 setting for $1 \mathrm{~h}$, until the solution was clear. The mixture was allowed to cool after which it was made up to $50 \mathrm{ml}$ with de-ionized water. The total nitrogen was determined colorimetrically using the method as described by Okalebo et al. [22]. Percentage nitrogen was calculated using the equation $Y=$ $0.026 x-0.003$ and $R^{2}=0.974$ obtained from the calibration curve using various concentration of the standards. The protein content was determined by multiplying the Nitrogen content value by 6.25 .

\subsection{Biochemical Evaluation of Diets on Rats Tissues}

Rats were grouped and fed with compounded experimental feed and water ad libitum, but starved for 12 hours before the start of the experiment. All the animals from each group were sacrificed by chloroform anesthesia 24 hr after respective 14 days of feed trial and water intake.

\subsection{Preparation of Tissue Homogenates}

Tissues were carefully removed from the sacrificed animals using a pair of gloves, dissecting set and collected in $15 \mathrm{ml} 0.25 \mathrm{~N}$ sucrose and then homogenized. $1 \mathrm{~g}$ each of tissue (brain, liver, kidney, heart, stomach, small intestine and spleen) was weighed and homogenized in ice-cold $10 \mathrm{ml}$ tris buffer (pH 7.8) using a triston homogenizer. The homogenates were centrifuged using the Beckman model TJ-6 refrigerated centrifuge (USA) at 2000 rpm for 10 minutes. The supernatant was carefully decanted into specimen bottles, kept frozen overnight to ensure maximum release of the enzymes in the tissue cells [23].

\subsection{Determination of Serum Triglycerides \& Total Cholesterol}

Total cholesterol \& triglycerides were determined by collecting blood samples in the yellow cap test tubes coated with clot activator and inside the tube a barrier gel presented at the bottom, used for serum separation. The serum was then rapidly spun with a centrifuge in order to remove the blood cells or clot.

\subsection{Determination of Serum Lipids}

\subsubsection{Determination of Serum Triglyceride (TG)}

The methods of Allain [24], Trisnder [25], Tietz [26] [27] using the Synchron Systems Multi Calibrator for the quantitative determination of total TG in the serum. This method used the Triglycerides glycerol phosphate oxidase (GPO) reagent to measure the TG concentration using a timed end point determination. Triglycerides in the sample were hydrolyzed by lipase to glycerol and free fatty acids. This was followed by a sequence of three coupled enzymatic reactions whereby Glycerol Kinase (GK), Glycerophosphate oxidase (GPO) and Horseradish peroxidase (HPO) causing the oxidative coupling of 3,5-dichloro-2-hydroxybenzenesulphonic acid (DHBS) with 4 -amino antipyrine to form a red quinoneimine red dye.

Triglycerides $\stackrel{\text { Lipase }}{\longrightarrow}$ Glycerol + fatty acids 


$$
\begin{gathered}
\text { Glycerol }+ \text { ATP } \stackrel{\text { Glycerol Kinase }}{\longrightarrow} \text { Glycerol-3-phosphate }+ \text { ADP } \\
\text { Glycerol-3-phospate }+\mathrm{O}_{2} \stackrel{\text { GPO }}{\longrightarrow} \text { Dihydroxy acetone }+\mathrm{H}_{2} \mathrm{O}_{2} \\
2 \mathrm{H}_{2} \mathrm{O}_{2}+\text { 4-Aminoantipyrene }+ \text { DHBS } \stackrel{\text { HPO }}{\longrightarrow} \text { Quinoneimine dye }+2 \mathrm{H}_{2} \mathrm{O}_{2}
\end{gathered}
$$

The Synchron System automatically measured out $10 \mu \mathrm{l}$ of the sample and $1000 \mu \mathrm{l}$ of the TG reagent into the cuvette. The change in absorbance was monitored by the system at $520 \mathrm{~nm}$. Change in absorbance was directly proportional to the concentration of triglycerides in the sample and is used by the system to calculate and express TG concentration.

\subsubsection{Determination of Serum Total Cholesterol}

The methods of Greling and Gresner [28] using the CHOL reagent was adopted. The Synchron system automatically proportions $10 \mu \mathrm{l}$ of the sample (rat's serum) and $1000 \mu \mathrm{l}$ of the CHOL reagent into the cuvette, both sample and reagent were mixed and the absorbance was read at $546 \mathrm{~nm}$ within $1 \mathrm{hr}$. The change in absorbance was directly proportional to the concentration of cholesterol in the sample and is used by the system to calculate and express cholesterol concentration.

\subsection{Determination of Tissue Enzyme Activities}

\subsubsection{Assay of Lactate Dehydrogenase Activity}

The method described by Wrobleski and La Due [29] was employed in the assay of Lactate Dehydrogenase (LDH) using Randox kits. Two portions were labeled sample and blank on a micro-titre plate. Into the well la-

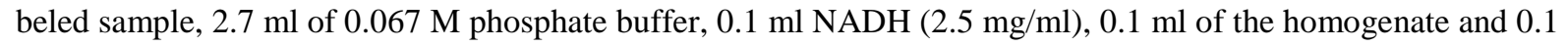
$\mathrm{ml}$ of the substrate were pipetted. Into the blank well was measured $3 \mathrm{ml}$ of distilled water. The blank was used to set zero, and the absorbance was read at $340 \mathrm{~nm}$ using the Biotek micro-titre plate reader (S/N 236255, USA), over a period of 3 minutes at 1 min intervals. The activity of the enzyme was calculated using the formula:

$$
\operatorname{Activity}(\mathrm{IU} / \mathrm{l})=\frac{\Delta A / \min \times 1000 \times V \times F}{6.3 \times v \times l}
$$

where; $\Delta A / \min =$ change in absorbance per minute; $V=$ total reaction volume; $F=$ dilution factor; $V=$ volume of homogenate; $l$ = light path; 1000 = factor to allow measurement in nmol; 63 = extinction coefficient.

\subsubsection{Determination of Tissue Creatine (CRT)}

The determination was based on the method described by Rosalki, [30] modified by Tietz, [26]. The CRT reagent was used for the quantitative determination of creatine kinase in serum or plasma. In the reaction, CRT catalyzes the transfer of a phosphate group from creatine phosphate to ADP with the subsequent formation of ATP. The formation of ATP is measured through the use of two coupled reactions catalyzed by hexokinase (HK) and glucose-6-phosphate dehydrogenase (G6PD) which results in the formation of NADH from NADP. The Synchron System automatically measures out the appropriate volumes of both the sample and reagent in the ratio 1: 20 respectively into the cuvette. The change in absorbance was monitored by the system at $340 \mathrm{~nm}$. Change in absorbance was directly proportional to the concentration of creatine kinase in the sample and is used by the system to calculate and express CRT concentration.

\subsubsection{Determination of Total Cholesterol Content in Organs of Rats}

The method Greling and Gresner [28] using the Randox kit CHOL reagent was adopted. $10 \mu \mathrm{l}$ of the sample (tissue homogenate) and $1000 \mu \mathrm{l}$ of the Chol reagent were measured and mixed in a micro-titre plate, and the initial absorbance at $546 \mathrm{~nm}$ was read after five-minute incubation at $37^{\circ} \mathrm{C}$, against $10 \mu \mathrm{l}$ of the standard.

$$
\text { Concentration of Chol in sample }=\frac{\Delta \text { A sample }}{\Delta A \text { standard }} \times C \text { standard }
$$

where: $A=$ Change in Absorbance, $C=$ Change in Concentration.

\subsubsection{Assay of Glucose Concentration (GLUC/POD/PAP)}

The procedure described by Lott [31] and Dingeon \& Ann [32] using Randox kits were used for the assay. 
Glucose oxidase (GOD) converts the sample Glucose into gluconate. The Hydrogen-peroxide $\left(\mathrm{H}_{2} \mathrm{O}_{2}\right)$ produced in the reaction is degraded by peroxidase (POD) and gives a colored product, Phenol and 4-Aminoantipyrine which is measurable using Trinder indicator reaction at $505 \mathrm{~nm}$. The increase in absorbance correlates with the glucose concentration of the sample.

$$
\begin{gathered}
\text { Glucose }+\mathrm{O}_{2} \rightarrow \text { GOD Gluconic acid }+\mathrm{H}_{2} \mathrm{O}_{2} \\
2 \mathrm{H}_{2} \mathrm{O}_{2}+\text { Phenol }+ \text { 4-AminoantipyrineRed quinine }+4 \mathrm{H} \rightarrow \mathrm{POD}_{2} \mathrm{O}
\end{gathered}
$$

One vial of (R2) was dissolved in appropriate amount of (R1). $5 \mu \mathrm{l}$ of the sample and $500 \mu \mathrm{l}$ of the Gluc-Pap reagent were mixed in a micro-titre plate, and the initial absorbance at $505 \mathrm{~nm}$ was read after ten-minute incubation at $37^{\circ} \mathrm{C}$, against $5 \mu \mathrm{l}$ of the standard.

$$
\text { Calculation. } \frac{A \text { sample }}{A \text { standard }} \times C \text { standard }
$$

where: $A=$ Absorbance; $C=$ Concentration.

\subsection{Statistical Analysis}

Significant differences between means of experiments were determined by least significant difference. SPSS 14.0 [33] statistical tool was used to analyze the data obtained. Results were considered statistically significant at $\mathrm{p}<0.05$ with Duncan's multiple range test [34].

\section{Results}

\subsection{Proximate Analysis of Experimental Diets}

The data on the proximate analysis of formulated diets is presented in Table 1. The crude protein content was significantly high $(\mathrm{p}<0.001)$ whereas crude fat content was highest $(\mathrm{p}<0.001)$ in the WSCF as compared with the positive control diet. All formulated diets had sufficient nutrients required for growth and development of experimental animals.

\subsection{Organ-Body Weight}

Organ/body weight ratio of rats fed with the test and control diets are represented in Figure 1 \& Figure 2 respectively. Figure 1 showed that the liver/body ratio of rats fed with CSKFBD, WSKFBD and PKFBD were significantly higher $(\mathrm{p}<0.01)$ compared to those in the control groups (positive and negative) respectively; no significant difference $(\mathrm{p}>0.05$ ) was observed in the brain/body, heart/body, stomach/body, small Intestine/body, kidney/body and spleen/body weight ratio of rats fed with the processed fillet diet compared to those fed with the control diets respectively. In Figure 2 rats fed with the SHBBD revealed that the liver/body and small Intestine/body weight ratios had the highest $(\mathrm{p}<0.001)$ ratios in the following order of decreasing magnitude when compared to the control groups i.e., CSHBBD $>$ WSHBBD $>$ PSHBBD $>$ S-GBD $>$ ZPD. No difference $(p>$ 0.05) was observed in the brain/body, heart/body, stomach/body and spleen/body weight ratio of rats fed with the SHBBD compared to those fed with the control diets respectively.

\subsection{Total Triglycerides \& Cholesterol Levels of Rats Fed with Control and Test Fillet and SHB Diets}

The serum triglycerides \& total cholesterol levels of rats fed with the test and control diets are represented in Figure 3 and Figure 4 respectively. Figure 3 showed that there was no difference $(p>0.05)$ in the levels of triglycerides \& total cholesterol in rats fed with fillet diet compared to the positive control.

\subsection{Tissue Creatinine, Cholesterol and Glucose Activities in Rats Fed with Control and Test (Fillet) Diets}

Tissue enzyme activities for LDH of rats fed with the test and control diets are represented in Figure 5. The 


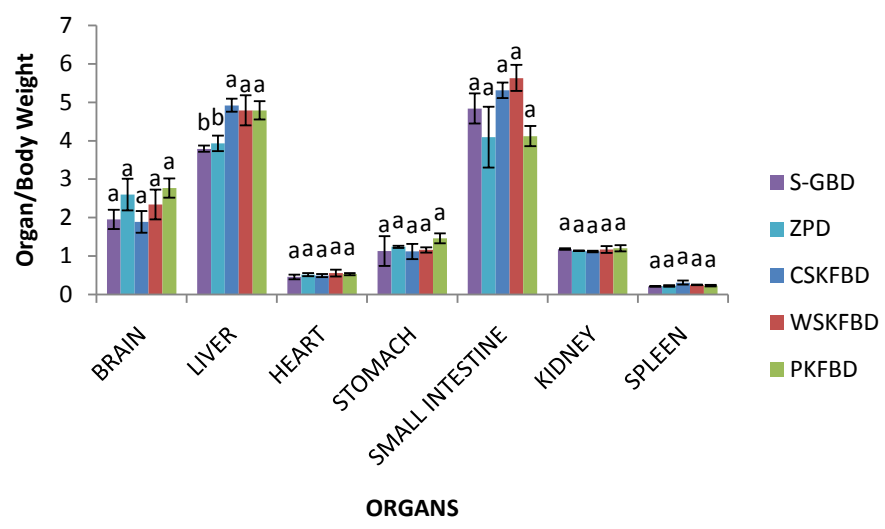

Figure 1. Organ/Body weight o rats fed on control and test (Fillet) diet ${ }^{*}{ }^{*}$ Values are means of 3 determinations \pm SEM. $\mathrm{n}=$ 3. Bars with the same colour but different letters are significantly different $(\mathrm{p}<0.05 \mathrm{~K})$. CSFBD $=$ coal smoked kote fillet meal based diet, WSKFBD= wood smoked kote fillet meal based diet, PKFBD = poached kote fillet meal based diet; S-GBD: Soy bean \& Groundnut cake meal based diet (Positive control); ZPD: Zero protein diet (Negative control).

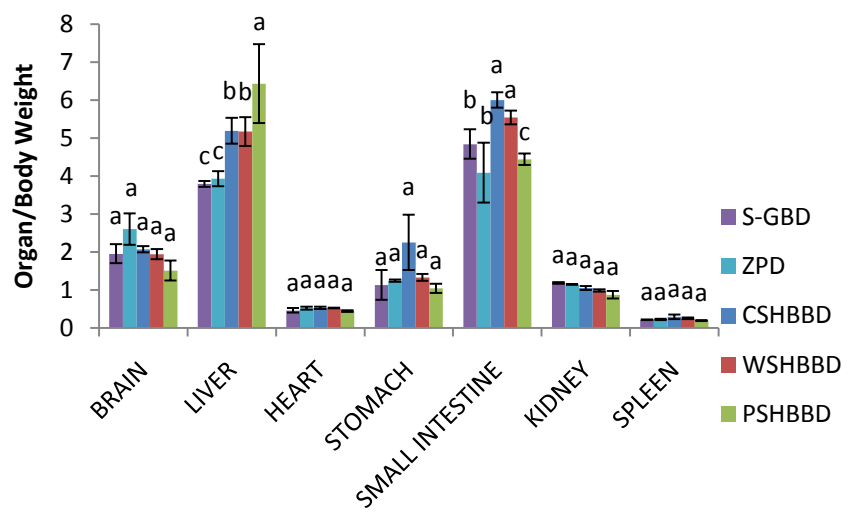

ORGANS

Figure 2. Organ/Body weight of rats fed on control and test (SHB) diet . . Values are means of 3 determinations \pm SEM. $\mathrm{N}=$ 3. Bars with the same colour but different letters are significantly different $(\mathrm{p}<0.05)$. CSSHBBD: charcoal smoked kote SHB meal based diet; WSSHBBD: wood smoked kote SHB meal based diet; PSHBBD: poached kote SHB meal based diet; S-GBD: Soy bean \& Groundnut cake meal based diet (Positive control); ZPD: Zero protein diet (Negative control).

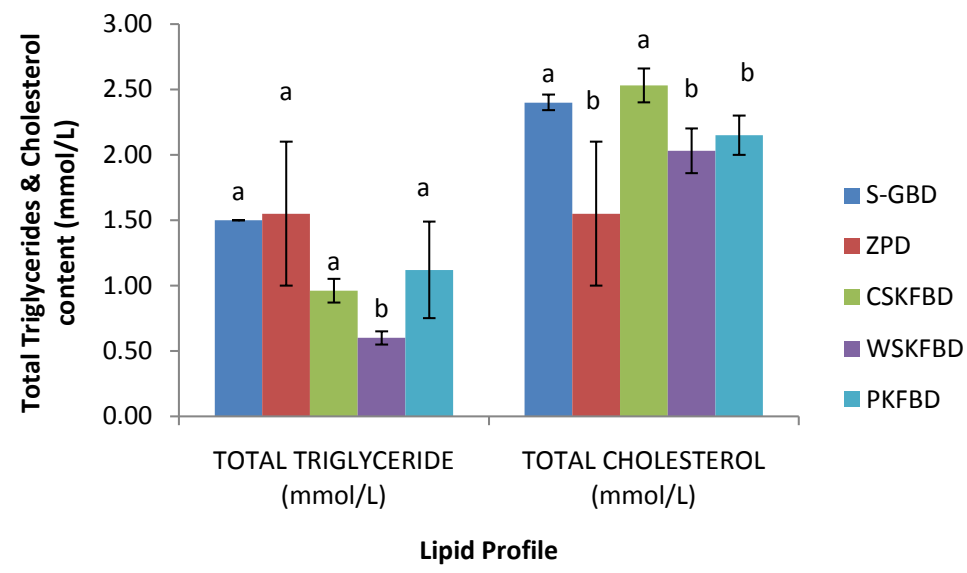

Figure 3. Lipid profile of rats fed with control and test (fillet) diets. *Values are means of 3 determinations \pm SEM. $n=3$. Bars with the same colour but different letters are significantly different $(\mathrm{p}<0.05)$. CSKFBD $=$ coal smoked kote fillet meal based diet, WSKFBD = wood smoked kote fillet meal based diet, PKFBD = poached kote fillet meal based diet; S-GBD: Soy bean \& Groundnut cake meal based diet (Positive control); ZPD: Zero protein diet (Negative control), TG = Triglyceride. 


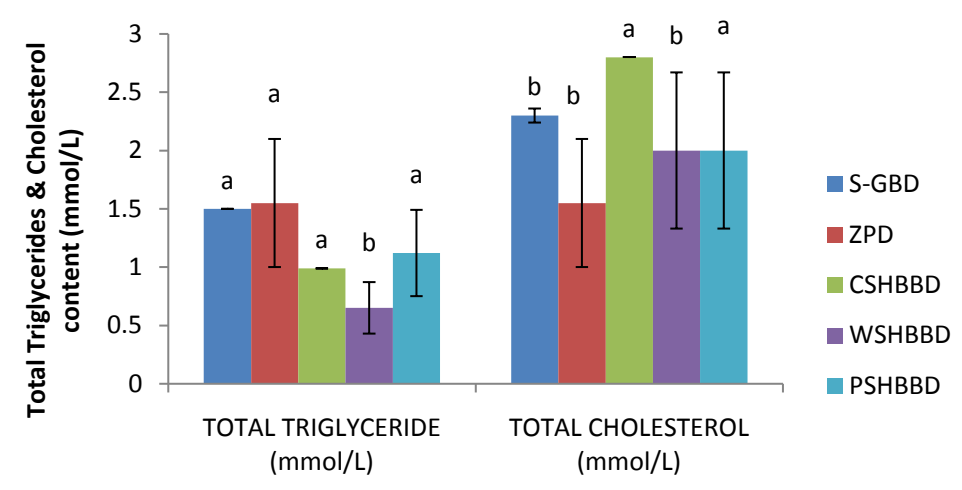

Lipid Profile

Figure 4. Selected lipid profile of rats fed on control and test (SHB) diets. ${ }^{*}$ Values are means of 3 determinations \pm SEM. $n=$ 3. Bars with the same colour but different letters are significantly different $(\mathrm{p}<0.05)$. CSSHBBD: charcoal smoked kote SHB meal based diet; WSSHBBD: wood smoked kote SHB meal based diet; PSHBBD: poached kote SHB meal based diet; S-GBD: Soy bean \& Groundnut cake meal based diet (Positive control); ZPD: Zero protein diet (Negative control); TG= Triglyceride.

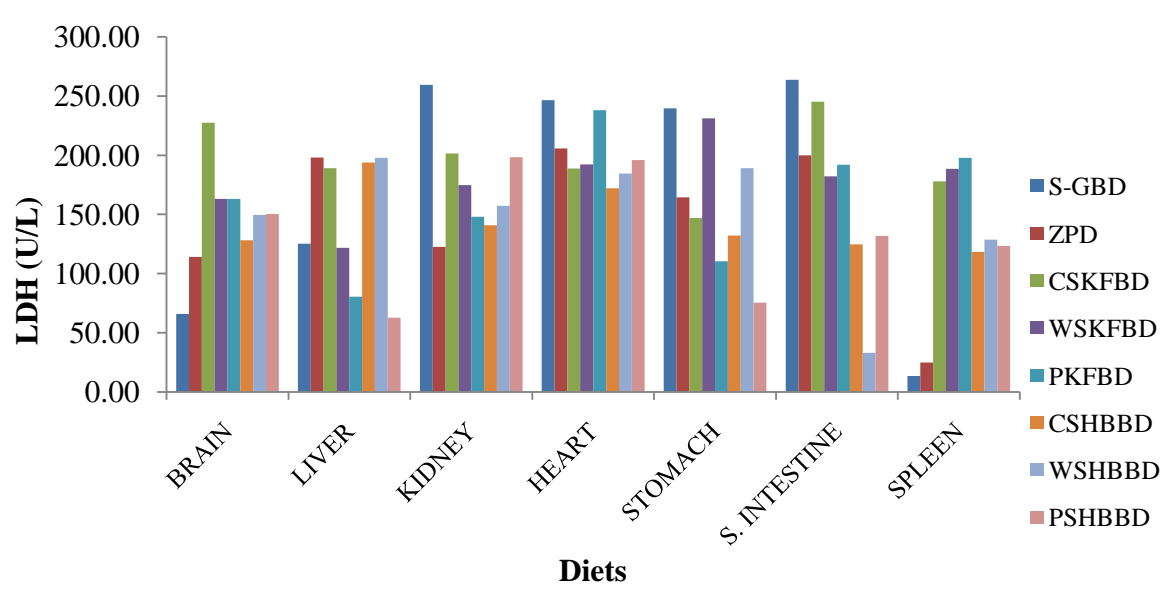

Figure 5. Levels of tissue LDH level of rats fed with control and test diets*. *CSKFBD: charcoal smoked kote fillet meal based diet; WSKFBD: wood smoked kote fillet meal based diet; PCFBD: poached kote fillet meal based diet; CSHBBD: charcoal smoked SHB meal based diet; WSHBBD: wood smoked cote SHB meal based diet; PSHBBD: poached SHB meal based diet; S-GBD: Soy bean \& Groundnut cake meal based diet (Positive control); ZPD: Zero protein diet (Negative control). $\mathrm{p}<0.05 . \mathrm{n}=3$.

LDH activities in the brain, liver and spleen of rats fed with the test diets were increased $(p<0.05)$ compared to the positive control; also all values obtained fell within the accepted clinical range. Figures 6-8 show the activities of CRT, CHOL and GLUC-PAP, respectively in the brain, liver, kidney, heart, stomach, small intestine and spleen of rats fed with test and control diets. Figure 6 showed that levels of activity of CHOL (Figure 7) was significantly reduced $(\mathrm{p}<0.05)$ all selected organs (brain, liver, kidney, heart, stomach, small intestine and spleen) of rats fed with the coal smoked fillet and SHB diets respectively compared to the positive control diet. In addition, GLUC-PAP increased $(p<0.05)$ in all selected tissues of rats fed on the fillet, while GLUC-PAP levels of those fed on the SHB diet reduced $(\mathrm{p}<0.05)$ compared to the control. It is paramount to note also that Glucose level fell within normal clinical range of 2.78 - 7.56 for all tested animal organs (brain, liver, kidney, heart stomach, small Intestine and spleen) of animals fed on the experimental diets compared to those on control diets.

Figure 8 shows the CRT levels of rats fed with test and control diets respectively. Activities of the CRT for all selected tissues were significantly higher $(\mathrm{p}<0.05)$ in animal fed with the smoked filet and SHB diet respectively compared to those fed with the positive control meal based diets. Nonetheless this observed increase was clinically insignificant because the CRT values were within the clinically accepted range of 11 - 90 umol/l. In 


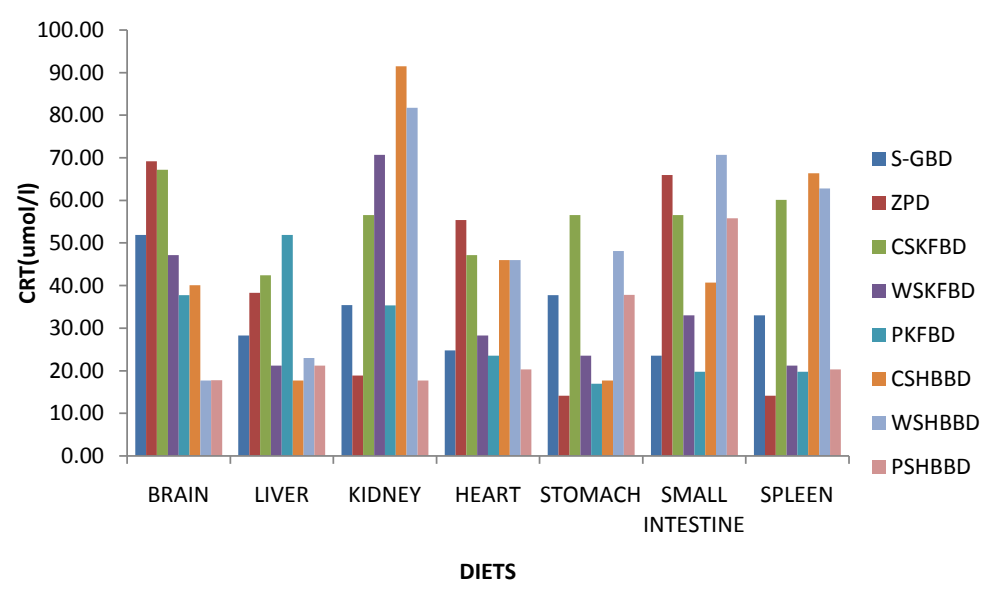

Figure 6. Levels of tissue CRT level of rats fed with control and test diets*. *CSKFBD: charcoal smoked kote fillet meal based diet; WSKFBD: wood smoked kote fillet meal based diet; PCFBD: poached kote fillet meal based diet; CSHBBD: charcoal smoked SHB meal based diet; WSHBBD: wood smoked cote SHB meal based diet; PSHBBD: poached SHB meal based diet; S-GBD: Soy bean \& Groundnut cake meal based diet (Positive control); ZPD: Zero protein diet (Negative control). $\mathrm{p}<0.05 . \mathrm{n}=3$.

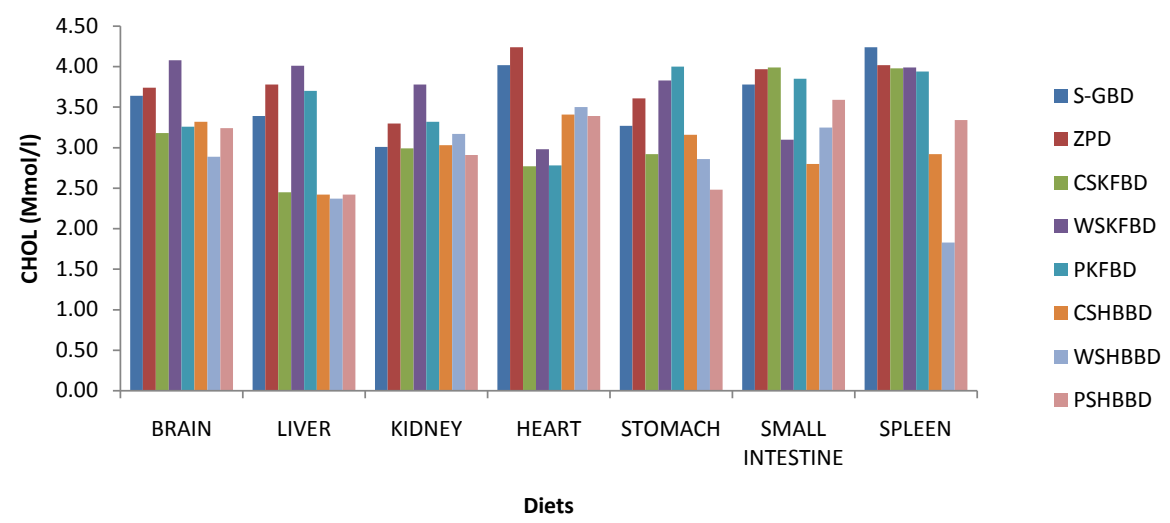

Figure 7. Levels of tissue CHOL level of rats fed control and test diets ${ }^{*} .{ }^{*}$ CSKFBD: charcoal smoked kote fillet meal based diet; WSKFBD: wood smoked kote fillet meal based diet; PCFBD: poached kote fillet meal based diet; CSHBBD: charcoal smoked SHB meal based diet; WSHBBD: wood smoked cote SHB meal based diet; PSHBBD: poached SHB meal based diet; S-GBD: Soy bean \& Groundnut cake meal based diet (Positive control); ZPD: Zero protein diet (Negative control). $\mathrm{p}<0.05$. $\mathrm{n}=3$.

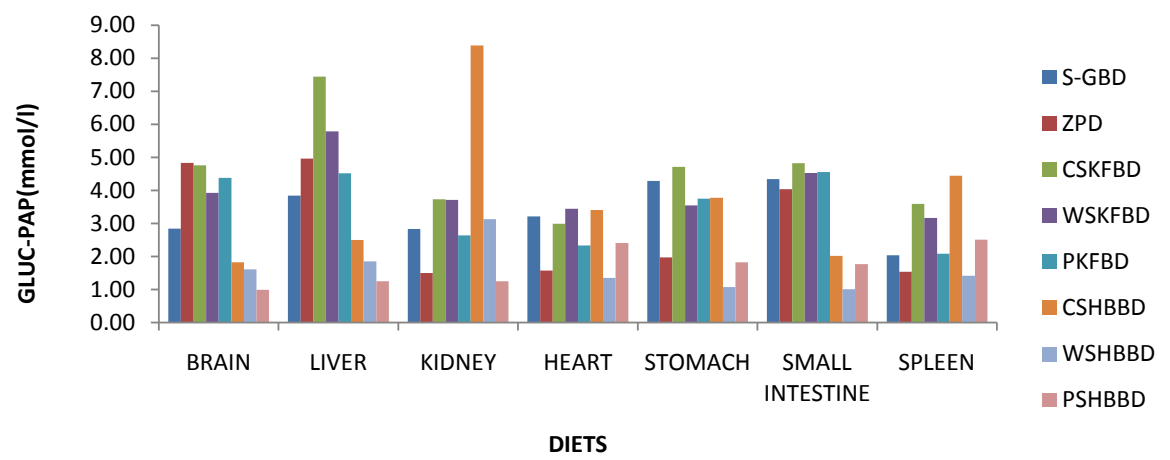

Figure 8. Levels of tissue GLUC-PAP level of rats fed control and test diets*. *CSKFBD: charcoal smoked kote fillet meal based diet; WSKFBD: wood smoked kote fillet meal based diet; PCFBD: poached kote fillet meal based diet; CSHBBD: charcoal smoked SHB meal based diet; WSHBBD: wood smoked cote SHB meal based diet; PSHBBD: poached SHB meal based diet; S-GBD: Soy bean \& Groundnut cake meal based diet (Positive control); ZPD: Zero protein diet (Negative control). $\mathrm{p}<0.05 . \mathrm{n}=3$. 
crease in CRT is clinically indicative of Muscular dystrophy or wasting disease, this was not the case in present study because rats fed on the fish meal based (fillet and SHB) diets performed significantly better $(p<0.05)$ than those in the positive control groups.

\section{Discussion}

The role of test and control diets on protein digestibility and bioavailability, in weaned male rats showed that the test and control diets conformed to the recommended feeding protocol [35] [36] and were adequate to meet growth requirements of the weaned rats. Although the crude fat content was highest $(p<0.001)$ in the WSCF compared with the positive control, this was not significant $(p>0.05)$ because the observed value was less than 30\% reported by Delorme and Gordon, [37] and Benevenga et al, [38] that cause a decrease in the growth of rats. Furthermore, the analyzed nutrients components in test and controls diets fell within the acceptable recommendation range of the nutrient required for laboratory animal. Thus values for all the nutrients in test compared well with the positive and were similar to those reported by Benevenga et al. [38].

The organ to body weight ratio gives a proportional size of the organ to body weight. It has been suggested that the use of organ-body weight ratios may be valuable in evaluating the relationship between certain experimental situations and the biological response of a test organism [39]. The liver being the major organ carrying out metabolic and detoxification processes is unique among the body's vital organs in that it can be regenerated. WSKFBD had the highest organ/body weight in the small intestine/body of animals in the fillet, while PSHBBD was highest in the liver/body and CSHBBD in Stomach/body and small intestine/body ratios of animals fed on the SHB based diets compared with the control. Organ weight can be the most sensitive indicator of an effect of an experimental compound, as significant differences $(\mathrm{p}<0.05)$ in organ weight between treated and untreated (control) animals may occur in the absence of any morphological changes [40]. Thus the organ-body weight ratio showed better $(\mathrm{p}<0.05)$ performance in animals placed on the SHB meal based diets in the brain, liver, stomach and small intestine compared to those placed with the fillet and control diet respectively.

Serum cholesterol is a term that includes the total level of cholesterol that is found in the bloodstream, it includes identifying all types or classes of cholesterol that are found in the system [41]. This helpful measurement makes it possible to determine if the balance between the HDL (good cholesterol) and LDL (bad cholesterol) is within acceptable limits. While the presence of HDL is beneficial to maintaining organ health and providing the body with necessary energy, the presence of LDL can lead to blockages that may lead to problems with the heart and lungs. Levels of serum cholesterol and triglycerides in present investigation were between $1.55-2.80$ and $0.60-1.55$ respectively. In animals fed with test and control diets, these values were within the accepted clinical range of $<5.0 \mathrm{mmol} / \mathrm{l}$ (cholesterol) and $<1.70 \mathrm{mmol}$ (triglycerides). However the significantly lower $(\mathrm{p}<0.05$ ) levels of total cholesterol in rats fed with the SHB diet compared with those in the control group confirms the report of Ruothalo, [42] and Greg, [43] that foods with healthy fats, such as monounsaturated fat and omega-3 fatty acids, can improve serum cholesterol levels when in the correct ratio with omega-6 fatty acid.

Lactate Dehydrogenase (LDH) is an oxido-reductase that catalyzes the inter-conversion of lactate and pyruvate [44] and is involved in producing energy. It is released from damaged cells in many areas of the body, including the liver. When disease or injury affects tissues containing LDH, the cells release LDH into the bloodstream, where it is identified in higher than normal levels [45]. Therefore, LDH is most often measured to evaluate the presence of tissue or cell damage. LDH enzyme is widely distributed in tissues particularly the heart, liver, kidney, brain, blood cell lungs, and muscles. LDH levels of present investigation in the kidney and heart of rats fed with the fillet diet were significantly reduced $(\mathrm{p}<0.05)$ compared to the controls.

Conversely, LDH level was elevated $(\mathrm{p}<0.05)$ in the brain and spleen of rats fed on the test diet compared to the controls, although within accepted clinical range $(<746 \mathrm{U} / \mathrm{l})$. The spleen is the organ that removes old and damaged RBCs from the circulation which is matched by production of new RBCs in the bone marrow. When the spleen is dysfunctional, blood LDH is high [27]. Elevated serum LDH levels have been observed in a variety of disease states [46]. The highest levels are seen in patients with megaloblastic anaemia, disseminated carcinoma and shock. Moderate increases occur in muscular disorders, nephritic syndrome and cirrhosis. Mild increases of LDH have been reported in cases of myocardial or pulmonary infarction, leukaemia, haemolytic anaemia and non-viral hepatitis [47]. Therefore the mild increases in LDH levels of rats fed on the test diets compared to the controls, was not significant ( $p>0.05$ ), this is because all values fell within the accepted clinical range.

Creatinine (CRT) is one of the metabolites of the body that is usually produced in the liver and then excreted 
via the kidneys. Creatinine is naturally produced in the human body from amino acids primarily in the kidney, liver, small intestine and spleen [48]. It is transported in the blood for use by muscles. The daily demand for CRT is met either by intestinal absorption of dietary CRT or by de novo CRT biosynthesis [49]. In the present study however, with the exception of the brain and liver tissues, rats fed on the SHB diet, all other tissues of animals fed on the processed test diets had significantly higher $(\mathrm{p}<0.01)$ CRT levels compared to the controls. Furthermore, CRT values for all selected tissues examined were within accepted range (11 - $90 \mathrm{umol} / \mathrm{l})$.

The kidney displayed a much higher CRT content; while the liver was considerably lower $(\mathrm{p}<0.05)$ in rats fed with processed fillet and SHB diets compared to those in the control groups. These observation were however, expected because the kidney plays a crucial role in CRT metabolism, on the other hand, it accomplishes urinary excretion of CRT, the purported end product of CRT metabolism in mammals [50] [51]. The liver is expected to have quite high amounts of creatinine because that is where the protein part from the food is broken down into useful energy and products like urea and creatinine that need to be eliminated from the body [52].

Nonetheless, a low liver creatinine level is thought to be of more significance because this shows that the metabolic reactions are not occurring in their full capacity in the liver and thus hinting towards liver disease [53]. Some reasons why the liver might have high creatinine levels is a diet that has a lot of meat and meat products in it, late stage of muscular dystrophy, prerenal azotemia and Myasthenia gravis [52]. The total CRT content in the present investigation was also lower $(\mathrm{p}<0.05)$ in the brain and heart for rats fed with the processed SHB diets, but a reverse trend was observed in rats fed with the processed fillet and control diets respectively.

Recent studies reported that CRT has a role in maintaining energy levels to the brain; also taking more creatinine through diets or supplements improves mental performance and boost memory and intelligence [54]. Lastly, the potential relationships between disturbances in CRT metabolism and diseases of heart, brain, and kidney have been reported. Elevated blood creatinine levels usually indicate kidney dysfunction or even kidney failure [55]. Thus findings in present study lends credence to the earlier observed content of essential amino acid, which was markedly present in high $(\mathrm{p}<0.05)$ amount in the raw and processed fillet and SHB. These essential amino acids might have boosted the protein contents of the processed fillet and SHB diets, thus giving rats fed with the test diets greater $(\mathrm{p}<0.05)$ performance compared to those in the control groups.

Cholesterol is an essential structural component of mammalian cell membranes and is required to establish proper membrane permeability and fluidity. Within the cell membrane, cholesterol also functions in intracellular transport, cell signaling and nerve conduction. It is synthesized in many types of tissues, but principally in the liver and intestinal wall of vertebrates. Cholesterol assays are used to screen for atherosclerotic risk and in the diagnosis and treatment of disorders involving elevated cholesterol levels as well as lipid and lipoprotein disorders [28]. The levels of tissue cholesterol for all experimental animals fed with test and control diets fell within the accepted range $(<5.17 \mathrm{mmol} / \mathrm{l})$.

The cholesterol levels were lower $(\mathrm{p}<0.05)$ in rats fed on SHB diet compared control groups respectively. Nonetheless observed elevation of the brain, liver, kidney and stomach Cholesterol, in rats fed with the WSFKBD, compared to those in the control group, were insignificant because values were within the accepted clinical range of $<5.17 \mathrm{mmol} / \mathrm{l}$. This confirms the reports of Caron and White, Caron and White, [54]; Calo, [55]; Burr et al., [56] and Chan and Cho, [57] that eating more of omega-3 fats actually boosts the levels of serotonin, known to fight depression, making brain cell membranes more effective. Result also agrees with the submission of Mozaffarian et al., [41] that eating foods with healthy fats, such as monounsaturated fat and omega-3 fatty acids, improves serum cholesterol levels.

The brain's dry weight is $60 \%$ fat, and cholesterol plays a vital role in neuron signaling and brain structure. In fact, one quarter of the body's free cholesterol is found in the nervous system [57]. Therefore when cholesterol drops too low, mood and behavior could be affected. Furthermore the synapses, involved in brain function, must have cholesterol to be formed. Brain signaling is all about membranes, and cell membranes are constructed from fat. Cholesterol and the omega ( 3 and 6 ) fatty acids are the most important molecules in the synapse. Recently studies reported more specifically that cholesterol depletion is known to impair the function of the serotonin $1 \mathrm{~A}$ \& 7 receptor [58], and reduces the ability of the serotonin transporter to move serotonin in and out of the synapse. It is also interesting to know that low serotonin in the spinal fluid is also associated with suicide, impulsive acts, hostility, aggression and low serotonin in the spinal fluid is associated with low cholesterol [54].

Thus the elevated levels of cholesterol in rats fed with the WSFKBD compared with the control may be related to the fat content of $T$. trachurus, which contained high $(\mathrm{p}<0.05)$ levels of $\omega 3$ and $\omega 6$ fatty acid earlier 
observed. This result agrees with the reports of Calo, [55] \& Burr et al., [56] that eating more of omega-3 fat acids boosts the levels of serotonin, known to fight depression, and make brain cell membranes more effective.

Nutrients and water are absorbed by the blood as it travels through the organs of the animal's digestive system. Animals cannot eat constantly yet their cells, tissues and organs must constantly be supplied with nutrients from which they can obtain energy. Glucose is an essential nutrient for the human body. It is the major energy source for many cells, which depend on the bloodstream for a steady supply, therefore, blood glucose levels are carefully maintained [55].

Glucose is the only fuel normally used by brain cells and a few other tissues in vertebrates e.g. liver. The brain uses glucose as a primary fuel for energy generation, because neurons cannot store glucose, they depend on the bloodstream to deliver a constant supply of this precious fuel [59]. The body's failure to metabolize carbohydrates results in the basic cellular failure to metabolize glucose. This causes the body cells to be unable to transport glucose from the bloodstream to the interior. The glucose then remains stored as body fat or glycogen, and/or is urinated out of the body [60]. Within the brain cells, glycogen is primarily stored in astrocytes, although ependymal and choroid plexus cells, as well as certain large neurons in the brainstem contain the polysaccharide [61]. Glycogen levels in brain are low compared to liver and muscle; however, the glycogen turnover rate is very rapid; its synthesis and breakdown are regulated by the two key enzymes glycogen phosphorylase and synthase [61].

Although values fell within accepted range (3.90 - $5.50 \mathrm{mmol} / \mathrm{L}$ ) brain, stomach, liver (except for CFKFBD) and stomach; glucose levels of the brain, liver, kidney and small intestine were slightly elevated in rats fed with the fillet diets but reduced ( $<<0.05$ ) in rats fed on SHB diets (except in kidney of CSHBBD) compared to the controls. The accumulation of glycogen in certain organs and tissues, especially the liver, kidneys, and small intestines, impairs their ability to function normally. Glycogen storage disease type I (also known as GSDI or von Gierke disease) is an inherited disorder caused, caused by autosomal recessive inborn error of carbohydrate metabolism caused by a defect in the glucose-6-phosphatase (G6Pase) enzyme complex that result by the build-up of a complex sugar called glycogen in the body's cells [59].

This was however not the case in the present study, because earlier observations showed that the variations observed in the kidney/body weight was not significant for rats fed on test diets compared to the controls. More so, levels of kidney LDH confirmed that this organ had no cellular damage. This agrees with the submission of Steven et al., [62] that the organ weight can be the most sensitive indicator of an effect of an experimental compound, as significant differences $(\mathrm{p}<0.05)$ in organ weight between treated and untreated (control) animals may occur in the absence of any morphological changes.

Determination of glucose concentration is important in the diagnosis and treatment of disorders of carbohydrate metabolism. Values higher or lower than the reference are of diagnostic significance. The levels are increased in diabetes mellitus, hyperthyroidism and in the hyperactivity of the pituitary gland. Decreased levels are observed in cases of overproduction of insulin by the pancreas, with tumours of the pancreas, as well as with hypo-function of the organs involved in glucose synthesis and carbohydrate metabolism [25] [31] [32].

Glucose is a major fuel for all body cells, especially brain (consumes $100 \mathrm{~g} /$ day) [59] result therefore implies that the animals were not starved, because liver, kidney \& skeletal muscles are involved in blood glucose homeostasis. Thus confirming earlier submission that the levels of nutrient supplied by all the compounded feeds (test (fillet \& SHB) and control), especially carbohydrate was in sufficient amount for animal growth.

\section{Conclusion}

Damage to cardiac musculature due to hypercholesterolemia has been reported to lead to leakage of cardiac biomarkers such as LDH, CRT and GGT [63]. Therefore, present study suggests that the test diets protected and prevented damage to the plasma membranes of not only the liver and heart, but also the brain, kidney, stomach, small intestine and spleen in the rats, further lending credence to earlier observations in serum and tissue cholesterol of rats fed with test diets compared to the controls. This study agrees with the reports of Grieling and Gressner, [28] that cholesterol, which is an essential structural component of mammalian cell membranes, is required to establish proper membrane permeability and fluidity, especially in diets that contain balanced amount of the PUFA. Lastly the coal smoked SHB was the best diet in terms of reduced levels of Chol \& TG as well as healthy growth of the rats, followed by wood smoked diets. Thus, processed kote SHB cut offs that are often discarded, could be a useful source of valuable nutrients in for human consumption and animal feed. 


\section{Acknowledgements}

The authors thank National Research Foundation (NRF) of South Africa for their financial support.

\section{References}

[1] Afolabi, O.A. (1984) Quality Changes in Nigeria Traditionally Processed Freshwater Species. International Journal of Food Science \& Technology, 18, 17-29.

[2] Andrew, A.E. (2001) Fish Processing Technology. University of Ilorin Press, Nigeria, 8-7.

[3] Nordov, A., Marchioli, R., Arnesen, H. and Videbaek, J. (2001) N-3 Polyunsaturated Fatty Acids and Cardiovascular Diseases. Lipids, 36, S127-S129. http://dx.doi.org/10.1007/s11745-001-0695-7

[4] Yamada, M., Wong, F.L., Kodama, K., Sasaki, H., Shimaoka, K. and Yamakido, M. (1997) Longitudinal Trends in Total Serum Cholesterol Levels in a Japanese Cohort, 1958-1986. Journal of Clinical Epidemiology, 50, 425-434. http://dx.doi.org/10.1016/S0895-4356(96)00423-4

[5] Simopoulos, A.P. (1997) Omega-3 Fatty Acids in the Prevention-Management of Cardio Vascular Disease. Canadian Journal of Physiology and Pharmacology, 75, 234-239.

[6] Rahman, Md.M., Pharm, B. and Pharm, M. (2014) Hypocholesterolemic Effects of Fish and Vegetable Oils on the Serum Lipid Profile of Experimentally Induced Hypercholesterolemic Rats. European Scientific Journal, 2014 Edition, 10, 475-482.

[7] Barter, P., Gotto, A.M., LaRosa, J.C., Maroni, J., Szarek, M., Grundy, S.M., Kastelein, J.J.P. and Bittner, V. (2007) HDL Cholesterol, Very Low Levels of LDL Cholesterol, and Cardio vascular Events. New England Journal of Medicine, 357, 1301-1310. http://dx.doi.org/10.1056/NEJMoa064278

[8] Naess, T. and Bergh, O. (1994) Calanoid Copepod Resting Eggs Can Be Surface-Disinfected. Aquacultural Engineering, 13, 1-9. http://dx.doi.org/10.1016/0144-8609(94)90021-3

[9] Piggott, G.M. and Tucker, B.W. (1990) Seafood: Effects of Technology on Nutrition. Marcel Dekker, Inc., New York, 221-228.

[10] Sargent, J.R. (1997) Fish Oils and Human Diet. British Journal of Nutrition, 78, 5-13. http://dx.doi.org/10.1079/BJN19970131

[11] Adeyemi, O.T. (2013) Effect of Processing on the Nutrient and Anti-Nutrient Composition of Atlantic Horse Mackerel (Trachurus trachurus) in Weaned Male Wistar Rats. Ph.D. Thesis. Babcock University, Ilisan Remo.

[12] ODS (2005) Dietary Supplement Fact Sheet: Omega-3 Fatty Acids and Health. http://ods.od.nih.gov/factsheets/Omega3FattyAcidsandHealth-HealthProfessional/

[13] Wake Forest University Baptist Medical Center (2008) Popular Fish, Tilapia, Contains Potentially Dangerous Fatty Acid Combination. Science Daily, 10 July 2008. www.sciencedaily.com/releases/2008/07/080708092228.htm

[14] Toppe, J., Aksnes, A., Hope, B. and Albrektsen, S. (2006). Inclusion of Fish Bone and Crab By-Products in Diets for Atlantic Cod, Gadus morhua. Aquaculture, 253, 636-645. http://dx.doi.org/10.1016/j.aquaculture.2005.09.015

[15] USDA (The Economic Research Service of the USDA) (2006) Global Food Markets: Briefing Rooms. http://www.ers.usda.gov/Briefing/

[16] Larsen (2012) Aspects of Physical and Chemical Alternatives to Proteins during Food Processing-Some Implication for Nutrition. British Journal of Nutrition, 108, S288-S297.

[17] FAO/UN (2007) State of the World's Forests 2007. Food and Agriculture Organization of the United Nations Rome. http://www.fao.org/docrep/009/a0773e/a0773e00.htm

[18] FAO/WHO (1991) Protein Quality Evaluation Report of Joint FAO/WHO Expert Consultation, Food and Agriculture Organization of the United Nations. FAO Food and Nutrition Paper, Rome. 51, 247. http://www.fao.org/ag/humannutrition/35978-02317b979a686a57aa4593304ffc17f06.pdf

[19] Association of Official Analytical Chemists (2002) Official Methods of Analysis. 17th Edition, AOAC, Washington DC.

[20] Reinik, M., Tamme, T., Roasto, M., Juhkam, K., Tenno, T. and Kiis, A. (2007) Polycyclic Aromatic Hydrocarbons (PAHs) in Meat Products and Estimated Pah Intake by Children and the General Population in Estonia. Food Additives and Contaminants, 24, 429-437. http://dx.doi.org/10.1080/02652030601182862

[21] Association of Official Analytical Chemists (1984) Official Methods of Analysis of the Association of Official Analytical Chemists. 14th Edition, AOAC, Arlington, 1141.

[22] Okalebo, J.R., Gathua, K.W. and Woomer, P.L. (2002) Laboratory Methods for Soil and Plant Analysis: A Working Manual. 2nd Edition, Tropical Soil Fertility and Biology Program, TSBF-CIAT and SACRED Africa, Nairobi, 128 p. 
[23] Oyedemi, S.O., Bradley, G. and Afolayan, A.L. (2011) Beneficial Effect of Aqueous Stem Bark Extracts of Strychnos henninhsii Gilg in Streptozotocin-Nicotinamide Induced Type 2 Diabetic Wista Rats. International Journal of Pharmacology, 7, 773-781.

[24] Allian, C.C., Poon, L.S., Chen, C.S.G., Richmond, W. and Fu, P.C. (1974) Enzymatic Determination of Serum Cholesterol. Clinical Chemistry, 20, 470-475.

[25] Trisnder, P. (1969) Determination of Blood Glucose Using an Oxidase-Peroxidase System with a Non-Carcinogenic Chromogen. Journal of Clinical Pathology, 22, 158-161. http://dx.doi.org/10.1136/jcp.22.2.158

[26] Tietz, N.W., Pruden, E.L. and Siggaard-Anderson, O. (1994) Liver Function. In: Burtis, C.A. and Ashwood, E.R., Eds., Tietz Textbook of Clinical Chemistry, W. B. Saunders Company, London, 1354-1374.

[27] Tietz, N.W. (1995) Clinical Guide to Laboratory Test. 3rd Edition, WB Saunders Company, Philadelphia, 384-387.

[28] Gressner, A.M. and Greiling, H. (1995) Lehrbuch der Klinischen Chernie and Pathobiochemie. 3rd Edition, Schattauer, Sluttgart/New York.

[29] Wroblewski, F. and La Due, J.S. (1955) Transaminase Activity in Human Blood. Annals of Internal Medicine, 45, 801.

[30] Rosalki, S.B. (1967) An Improved Procedure for Serum Creatine Phosphokinase Determination. Journal of Laboratory and Clinical Medicine, 69, 696-705.

[31] Lott, J.A. and Turner, K. (1975) Evaluation of Trinder's Glucose Oxidase Method for Measuring Glucose in Serum and Urine. Clinical Biochemistry, 21, 1754-1760.

[32] Dingeon, N., Collombel, C., Artru, C., Garat, A. and Friederich, A. (1975) Determination of Glomerular and Tubular Clearance in Children without Urine Collection. Pathologie Biologie, 23, 501-506.

[33] Statistical Package for Social Sciences for Windows, SPSS (2005) Computer Program, MS. for Windows, Version 14.00, SPSS Inc., Chicago, Release 14.0. http://www.Spss.com

[34] Duncan, D.B. (1955) Multiple Range and Multiple F-Test. Biometrics, 11, 1-5.

[35] Food and Agricultural Organization and World Health Organization (1991) Protein Quality Evaluation: Report of a Joint FAO/WHO Expert Consultation. Food and Nutrition Paper, Food and Agricultural Organization of the United Nations, Rome, 26-28, 51.

[36] Aduku, A.O. (2005) Tropical Feed Stuff Analysis Table. Department of Animal Science, Faculty of Agriculture, Ahmadu Bello University, Samaru-Zaria.

[37] Delorme, C.B. and Gordon, C.L. (1983) The Effect of Pectin on the Utilization of Marginal Levels of Dietary Protein by Weanling Rats. Journal of Nutrition, 113, 2432-2441.

[38] Benevenga, N.J., Calvert, C., Eckhert, C.D., Fahey, G.C., Greger, J.L., Keen, C.L., Knapka, J.J., Magalhaes, H., Oftedal, O.T., Reeves, P.G., Shaw, H.A., Smith, J.E. and Steele, R.D. (1995) Nutrient Requirements of Laboratory Animals. Fourth Revised Edition, Subcommittee on Laboratory Animal Nutrition, Committee on Animal Nutrition, Board on Agriculture, National Research Council, National Academy of Sciences, Washington DC, 1-79.

[39] Wilber, C.G. and Gilchrist, R.D. (1965) Organ Weight: Body Weight Ratios in the Mongolian Gerbil, Meriones unguiculatus. Chesapeake Science, 6, 109-114. http://dx.doi.org/10.2307/1351327

[40] Bailey, S.A., Zidell, R.H. and Perry, R.W. (2004) Relationships between Organ Weight and Body/Brain Weight in the Rat: What Is the Best Analytical Endpoint? Toxicologic Pathology, 32, 448-466. http://dx.doi.org/10.1080/01926230490465874

[41] Mozaffarian D., Micha R. and Wallace S. (2010) Effects On Coronary Heart Disease Of Increasing Polyunsaturated Fat In Place Of Saturated Fat: A Systematic Review And Meta-Analysis Of Randomized Controlled Trials. PLoS Med. 7, e1000252.

[42] Stentz, R., Bongaerts, R.J., Gunning, A.P., Gasson1, M. and Shearman, C. (2010) Controlled Protein Release from Viable Lactococcus lactis Cells. Applied and Environmental Microbiology, 76, 3026-3031. http://dx.doi.org/10.1128/AEM.00021-10

[43] Lu, F.X., Chauhan, A.K., Fernandes, S.M., Walsh, M.T., Wagner, D.D. and Davis III, A.E. (2008) The Effect of $\mathrm{C}_{1}$ Inhibitor on Intestinal Ischemia and Reperfusion Injury. American Journal of Physiology_Gastrointestinal and Liver Physiology, 295, G1042-G1049. http://dx.doi.org/10.1152/ajpgi.90460.2008

[44] Mittal, R., Wang, Y., Hunter, C.J., Gonzalez-Gomez, I. and Prasadarao, N.V. (2009) Brain Damage in Newborn Rat Model of Meningitis by Enterobacter sakazakii: A Role for Outer Membrane Protein A. Laboratory Investigation, 89, 263-277. http://dx.doi.org/10.1038/labinvest.2008.164

[45] Thomas, L. (1992) Labour und Diagnose. 4th Edition, Die Medizinische Verlagsgesellschachft, Margurg.

[46] Aaserud, R., Gramvik, P., Olsen, S.R. and Jensen, J. (1998) Creatinine Supplementation Delays Onset of Fatigue during Repeated Bouts of Sprint Running. Scandinavian Journal of Medicine \& Science in Sports, 8, 247-251. 
http://dx.doi.org/10.1111/j.1600-0838.1998.tb00478.x

[47] Achten, E., Boon, P., Van, D.E., Kerckhove, T., Caemaert, J., De Reuck, J. and Kunnen, M. (1997) Value of Single-Voxel Proton MR Spectroscopy in Temporal Lobe Epilepsy. American Journal of Neuroradiology, 18, 1131-1139.

[48] Berlet, H.H., Bonsmann, I. and Birringer, H. (1976) Occurrence of Free Creatine, Phosphocreatine and Creatine Phosphokinase in Adipose Tissue. Biochimica et Biophysica Acta, 437, 166-174. http://dx.doi.org/10.1016/0304-4165(76)90358-5

[49] Adams, G.R., Haddad, F. and Baldwin, K.M. (1994) Interaction of Chronic Creatine Depletion and Muscle Unloading: Effects on Postural and Locomotor Muscles. Journal of Applied Physiology, 77, 1198-1205.

[50] Christensen, M., Hartmund, T. and Gesser, H. (1994) Creatine Kinase, Energy-Rich Phosphates and Energy Metabolism in Heart Muscle of Different Vertebrates. Journal of Comparative Physiology B: Biochemical, Systemic, and Environmental Physiology, 164, 118-123. http://dx.doi.org/10.1007/BF00301652

[51] Kushmerick, M.J., Moerland, T.S. and Wiseman, R.W. (1992) Mammalian Skeletal Muscle Fibers Distinguished by Contents of Phosphocreatine, ATP, and $\mathrm{P}_{\mathrm{i}}$. Proceedings of the National Academy of Sciences of the United States of America, 89, 7521-7525. http://dx.doi.org/10.1073/pnas.89.16.7521

[52] Loike, J.D., Cao, L., Brett, J., Ogawa, S., Silverstein, S.C. and Stern, D. (1992) Hypoxia Induces Glucose Transporter Expression in Endothelial Cells. American Journal of Physiology_Cell Physiology, 263, C326-C333.

[53] Lee, H.J., Fillers, W.S. and Iyengar, M.R. (1988) Phosphocreatine, an Intracellular High-Energy Compound Is Found in the Extracellular Fluid of the Seminal Vesicles in Mice and Rats. Proceedings of the National Academy of Sciences of the United States of America, 85, 7265-7269. http://dx.doi.org/10.1073/pnas.85.19.7265

[54] Caron, M.F. and White, C.M. (2001) Evaluation of the Anti-Hyperlipidemic Properties of Dietary Supplements. Pharmacotherapy, 21, 481-487. http://dx.doi.org/10.1592/phco.21.5.481.34499

[55] Calo, L., Bianconi, L., Colivicchi, F., Lamberti, F., Loricchio, M.L., de Ruvo, E., et al. (2005) N-3 Fatty Acids for the Prevention of Atrial Fibrillation after Coronary Artery Bypass Surgery: A Randomized, Controlled Trial. Journal of the American College of Cardiology, 45, 1723-1728. http://dx.doi.org/10.1016/j.jacc.2005.02.079

[56] Burr, M.L. (1989) Fish and Cardiovascular System. Progress in Food Nutrition Science, 13, 291-316.

[57] Cho, C.S., Oh, B.H. and Shim, S.C. (2009) Synthesis of Quinolines by Ruthenium-Catalyzed Heteroannulation of Anilines with 3-Amino-1-Propanol. Journal of Heterocyclic Chemistry, 36, 1175-1178. http://dx.doi.org/10.1002/jhet.5570360510

[58] Nordlie, R.C., Foster, J.D. and Lange, A.J. (1999) Regulation of Glucose Production by the Liver. Annual Review of Nutrition, 19, 379-406. http://dx.doi.org/10.1146/annurev.nutr.19.1.379

[59] Rao, J., Oz, G. and Seaquist, E.R. (2006) Regulation of Cerebral Glucose Metabolism. Minerva Endocrinologica, 31, 149-158.

[60] Magistretti, P.J., Pellerin, L. and Martin, J.-L. (2000) Brain Energy Metabolism: An Integrated Cellular Perspective. American College of Neuropsychopharmacology. www.acnp.org/G4/GN401000064/

[61] Martens, D.H., Rake, J.P., Navis, G., Fidler, V., van Dael, C.M. and Smit, G.P. (2009) Renal Function in Glycogen Storage Disease Type I, Natural Course, and Renopreservative Effects of ACE Inhibition. Clinical Journal of the American Society of Nephrology, 4, 1741-1746. http://dx.doi.org/10.2215/CJN.00050109

[62] Bailey, S.A., Zidell, R.H. and Perry, R.W. (2004) Relationships between Organ Weight and Body/Brain Weight in the Rat: What Is the Best Analytical Endpoint? Toxicologic Pathology, 32, 448-466. http://dx.doi.org/10.1080/01926230490465874

[63] Sunmonu, T.O. and Afolayan, A.J. (2010) Protective Effect of Artemisia afra Jacq. on Isoproterenol-Induced Myocardial Injury in Wistar Rats. Food and Chemical Toxicology, 48, 1969-1972. http://dx.doi.org/10.1016/j.fct.2010.04.046 